Article

\title{
Rapid Ferric Transformation by Reductive Dissolution of Schwertmannite for Highly Efficient Catalytic Degradation of Rhodamine B
}

\author{
Jingyu Ran ${ }^{1, *(D)}$ and Bo Yu ${ }^{2}$ \\ 1 School of Chemical Engineering, Guizhou Institute of Technology, Guiyang 550003, China \\ 2 State Key Laboratory of Chemical Engineering, School of Chemical Engineering and Technology, \\ Tianjin University, Tianjin 300072, China; tjuyubo@163.com \\ * Correspondence: jingyuran@git.edu.cn; Tel.: +86-851-8834-9057
}

Received: 31 May 2018; Accepted: 5 July 2018; Published: 9 July 2018

\begin{abstract}
In this study, reductive dissolution of iron oxides was considered for the acceleration of the transformation from $\mathrm{Fe}$ (III) to $\mathrm{Fe}$ (II) to improve the degradation of rhodamine B (RhB) by potassium persulfate (PS) activation on schwertmannite. The addition of hydroxylamine (HA) showed an enhancement effect on the degradation at $\mathrm{pH} 3$ and 5, but insignificant efficiency of the addition was obtained at $\mathrm{pH}$ 9. The surface reduction from $\mathrm{Fe}(\mathrm{III})-\mathrm{OH}$ to $\mathrm{Fe}(\mathrm{II})-\mathrm{OH}$ by HA was considered dominant for the acceleration of PS activation through the reductive dissolution process, and the hydroxyl and sulfate radicals generated by the decomposition of surface complexes were main primary reactive oxidants that contributed to the degradation of RhB.
\end{abstract}

Keywords: ferric transformation; reductive dissolution; schwertmannite; heterogeneous

\section{Introduction}

Advanced oxidation processes (AOPs) are considered efficient for the abiotic degradation of organic pollutants in water treatment due to the high oxidation activity of radicals towards organics, especially biological toxic and non-degradable organics, which are difficult to be degraded by conventional or biological oxidation methods [1]. Recently, sulfate radicals $\left(\mathrm{SO}_{4}^{--}\right)$based AOPs has attracted considerable attention due to the high standard redox potential of $\mathrm{SO}_{4}^{--}$(2.6 V) [2], which is comparable to that of hydroxyl radicals $(\bullet \mathrm{OH}, 2.8 \mathrm{~V})$ [3]. As the important way to generate $\mathrm{SO}_{4}^{\bullet-}$, the activation of peroxymonosulfate (PMS) and persulfate (PS) has been widely studied via heating, UV irradiation and transition metals activated [4-12]. PS or PMS activation can also be achieved by transition metals $[4,5,11]$. Considering the environmental friendly nature and the advantages of cost effectiveness, $\mathrm{Fe}(\mathrm{II})$ has always been selected as the activator of PS or PMS for the generation of $\mathrm{SO}_{4}^{\bullet-}$ [13-15]. However, $\mathrm{Fe}(\mathrm{II}) / \mathrm{PS}$ process shows slow transformation from $\mathrm{Fe}(\mathrm{III})$ to $\mathrm{Fe}(\mathrm{II})$, which further results in low efficiency for PS or PMS activation and radicals generation [11,15]. Although many efforts have been made to accelerate the transformation from Fe(III) to Fe(II) by employing UV irradiation [16], electrochemistry [17] and reducing agents [15,18], the accumulation of ferric oxide sludge and acidic $\mathrm{pH}$ conditions still limit the widespread application [19]. To avoid the accumulation of ferric oxide sludge and extend the condition to neutral $\mathrm{pH}$, iron oxides such as ferrihydrite, lepidocrocite, goethite and hematite have been widely investigated as catalysts for heterogeneous AOPs [20-24]. However, the outer Fe(III) layer formed by the oxidation on iron oxides will passivate the surface of catalysts and inhibit the catalytic efficiency toward AOPs. The slow transformation of $\mathrm{Fe}(\mathrm{III})$ to $\mathrm{Fe}$ (II) still limits the peroxide or persulfate activation and radical generation.

Schwertmannite $(\mathrm{Sch})$ is a poorly crystalline $\mathrm{Fe}(\mathrm{III})$-oxyhydroxysulfate mineral, which always precipitates in sulfate-rich acid mine drainage (AMD). It is always represented as $\mathrm{Fe}_{8} \mathrm{O}_{8}(\mathrm{OH})_{8-2 x}\left(\mathrm{SO}_{4}\right)_{x}$, 
where $x$ varies from 1 to 1.75 [25,26]. Reductive dissolution is a dissolution process of ferric minerals with the release of $\mathrm{Fe}(\mathrm{II})$ from $\mathrm{Fe}(\mathrm{III})$ oxides to aqueous solutions. As hydroxylamine (HA) adsorbs onto the surface of iron oxides, surface complex of [Fe(III)-HA] forms followed by electron transfer between $\mathrm{Fe}(\mathrm{III})$ and $\mathrm{HA}$, which subsequently results in the formation of $\mathrm{Fe}(\mathrm{II})$ and semi-stable state surface complexes. Fe(II) will be directly released through the decomposition of surface complexes. Therefore, addition of HA enhanced the transformation from Fe(III) to Fe(II) on the surface, which results in good efficiency for the improvement of PS activation on schwertmannite. Although schwertmannite has been investigated as a new Fenton-like catalyst in the oxidation of phenol by hydrogen peroxide $\left(\mathrm{H}_{2} \mathrm{O}_{2}\right)$ [23], to the best of our knowledge, activation of PS on schwertmannite for heterogeneous AOPs has never been reported. Therefore, the objective of this study was to investigate the heterogeneous catalytic oxidation of rhodamine $\mathrm{B}(\mathrm{RhB})$ by PS and the effect of reductive dissolution of schwertmannite on the heterogeneous advanced oxidation process.

\section{Experimental Section}

\subsection{Materials and Chemicals}

Ferrous sulfate $\left(\mathrm{FeSO}_{4} \cdot 7 \mathrm{H}_{2} \mathrm{O}\right)$, ferric chloride $\left(\mathrm{FeCl}_{3} \cdot 6 \mathrm{H}_{2} \mathrm{O}\right)$, hydrogen peroxide $\left(\mathrm{H}_{2} \mathrm{O}_{2}\right)$, potassium persulfate (PS), hydroxylamine (HA), rhodamine B (RhB), tert-butyl alcohol (TBA) and methanol were of analytical reagent grade and purchased from Tianjin Guangfu Technology Development Co., Ltd. (Tianjin, China) All chemicals were used without further purification, and Milli-Q water was used throughout this study.

\subsection{Synthesis of Schwertmannite}

Schwertmannite was synthesized via $\mathrm{Fe}(\mathrm{II})$ oxidation method [27]: $16.45 \mathrm{~g} \mathrm{FeSO} \cdot 7 \mathrm{H}_{2} \mathrm{O}$ was dissolved in $1 \mathrm{~L}$ deionized water and reacted with $5.3 \mathrm{~mL} \mathrm{30} \% \mathrm{H}_{2} \mathrm{O}_{2}$. The solution became dark red, and a red-orange material precipitated immediately with the final $\mathrm{pH}$ of 2.5 after $24 \mathrm{~h}$. The solid was then centrifuged, washed three times and freeze-dried for further use.

\subsection{Catalytic Oxidation of $R h B$}

All experiments were performed in $150 \mathrm{~mL}$ triangular flasks with a constant stirring at $25^{\circ} \mathrm{C}$. Solutions with desired concentrations of $\operatorname{RhB}(0.5 \mathrm{M})$, PS $(0.5 \mathrm{M})$ and HA $(10 \mathrm{mM})$ were prepared before the reaction, respectively. In a typical experiment, $50 \mathrm{mg}$ schwertmannite solid was hydrated in deionized water for $1 \mathrm{~h}$ at a given $\mathrm{pH}$, which was adjusted to desired values by using $0.5 \mathrm{M}$ $\mathrm{HCl}$ or $\mathrm{NaOH}$ solution during the equilibration. After that, the prepared RhB, PS and HA solutions was added, and the desired initial $\mathrm{pH}$ was adjusted rapidly by using $0.5 \mathrm{M} \mathrm{HCl}$ or $\mathrm{NaOH}$ solution. After the addition of RhB, PS and HA, the final volume of the solution was $100 \mathrm{~mL}$, and the initial concentrations of iron oxides, RhB, PS and HA were $0.5 \mathrm{~g} / \mathrm{L}, 25 \mathrm{mM}, 5 \mathrm{mM}$ and 0-1 mM, respectively. Furthermore, $\mathrm{Fe}(\mathrm{III})$ as $\mathrm{FeCl}_{3}$ was employed and substituted for schwertmannite to investigate the effect of dissolved iron on the degradation process, the concentration of $\mathrm{Fe}(\mathrm{III})$ was $25 \mu \mathrm{M}$ after mixing. Besides, to understand the activation mechanism of PS on schwertmannite, methanol and TBA were employed as scavengers for radicals formed by the PS activation. After mixing of RhB, PS, and HA, methanol or TBA were added in to the system, and the concentrations were changed from 0 to $1 \mathrm{mM}$, respectively. During the oxidation experiments, samples were withdrawing regularly and centrifuged for $2 \mathrm{~min}$ at 12,000 rpm. The supernatant was then obtained for the determination of RhB and dissolved iron concentrations. All data were determined and collected by dual experiments.

\subsection{Characterization}

Morphology of the synthesized schwertmannite was characterized by field emission scanning electron microscopy (SEM, S4800, Hitachi, Tokyo, Japan) and high-resolution analytical transmission electron microscopy (TEM, Fei Tecnai G2 F20, FEI, Hillsboro, OR, USA). The crystalline structure of 
schwertmannite was characterized by powder X-ray diffraction pattern (XRD), which was employed by using $\mathrm{Cu} \mathrm{Ka} \mathrm{(1.54)} \mathrm{radiation} \mathrm{on} \mathrm{a} \mathrm{D/MAX} 2500$ X-ray diffractometer at the voltage of $40 \mathrm{kV}$ and

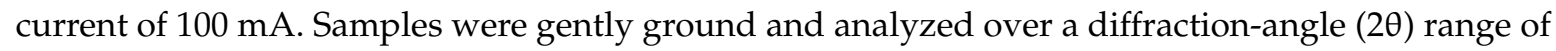
$2-90^{\circ}$, with scanning rate of $8^{\circ} / \mathrm{min}$. Concentration of RhB was determined at $550 \mathrm{~nm}$ by UV-Vis spectrophotometer (UV-6300, Mapada, Shanghai, China). Dissolved iron was measured by inductively coupled plasma-mass spectrometry (ICP-MS, 7700x, Agilent, Santa Clara, CA, USA).

\subsection{Computation Details}

Orbital energy analysis of intermediates was achieved by DMol3 module of Materials Studio 8.0, and the highest occupied molecular orbital (HOMO) energy level and lowest unoccupied molecular orbital (LUMO) energy level were studied to evaluate the energy needed for electrons to cross the energy barrier based on the frontier molecular orbital analysis [28].

\section{Results and Discussion}

\subsection{Characterization of Schwertmannite}

Schwertmannite was a Fe(III)-oxyhydroxysulfate oxide with poorly crystalline structure. Morphological analysis achieved by SEM and TEM suggests that the synthesized schwertmannite shows a spherical morphology with the diameter of $500 \mathrm{~nm}$ (Figure 1a,b). XRD analysis shows diffraction peaks as (201), (310), (212), (302), (522), (004) and (542)/(204) (Figure 1c), which are in good agreement with schwertmannite (JCPDS, No. 47-1775).

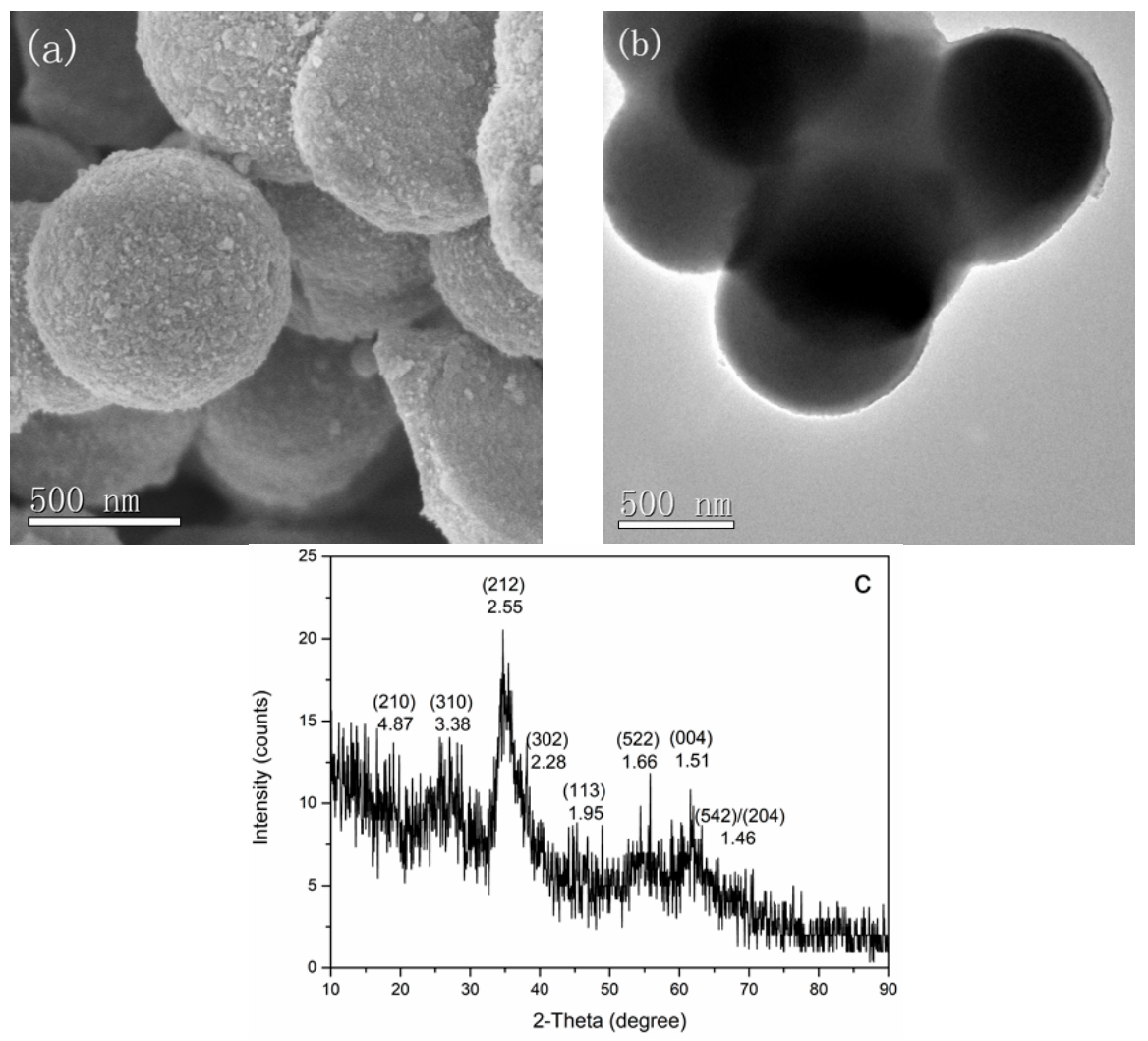

Figure 1. SEM (a); TEM (b); and XRD (c) analysis of synthesized schwertmannite. 


\subsection{Effect of HA on Degradation of RhB by PS on Schwertmannite}

As shown in Figure 2, RhB could be oxidized and degraded by PS activation on schwertmannite at $\mathrm{pH} 3,5$ and 9, and the degradation of $\mathrm{RhB}$ was more efficient in acid conditions. Concentrations of $\mathrm{RhB}$ decreased from $25 \mathrm{mM}$ to $0.5,3.0$ and $7.8 \mathrm{mM}$ in $360 \mathrm{~min}$ at $\mathrm{pH} 3,5$ and 9, respectively (Figure 2a). This suggests that schwertmannite shows good catalytic activity for radical generation from PS activation in heterogeneous AOPs. More than $90 \%, 84 \%$ and $37 \%$ of RhB was degraded in 30 min with the addition of $\mathrm{HA}$ at $\mathrm{pH} 3,5$ and 9, respectively (Figure $2 \mathrm{~b}$ ). Concentrations of RhB decreased rapidly from $25 \mathrm{mM}$ to $0.5,0.6$ and $9.7 \mathrm{mM}$ in $180 \mathrm{~min}$ at $\mathrm{pH} \mathrm{3,5}$ and 9, respectively. The rapid decreasing concentration of RhB with the addition of HA suggests an enhanced activation of PS by the acceleration of $\mathrm{Fe}(\mathrm{III})-\mathrm{Fe}(\mathrm{II})$ recycle $[15,18]$, which attributes to the reducing capacity of HA for the transformation from $\mathrm{Fe}(\mathrm{III})$ to $\mathrm{Fe}(\mathrm{II})[29,30]$.
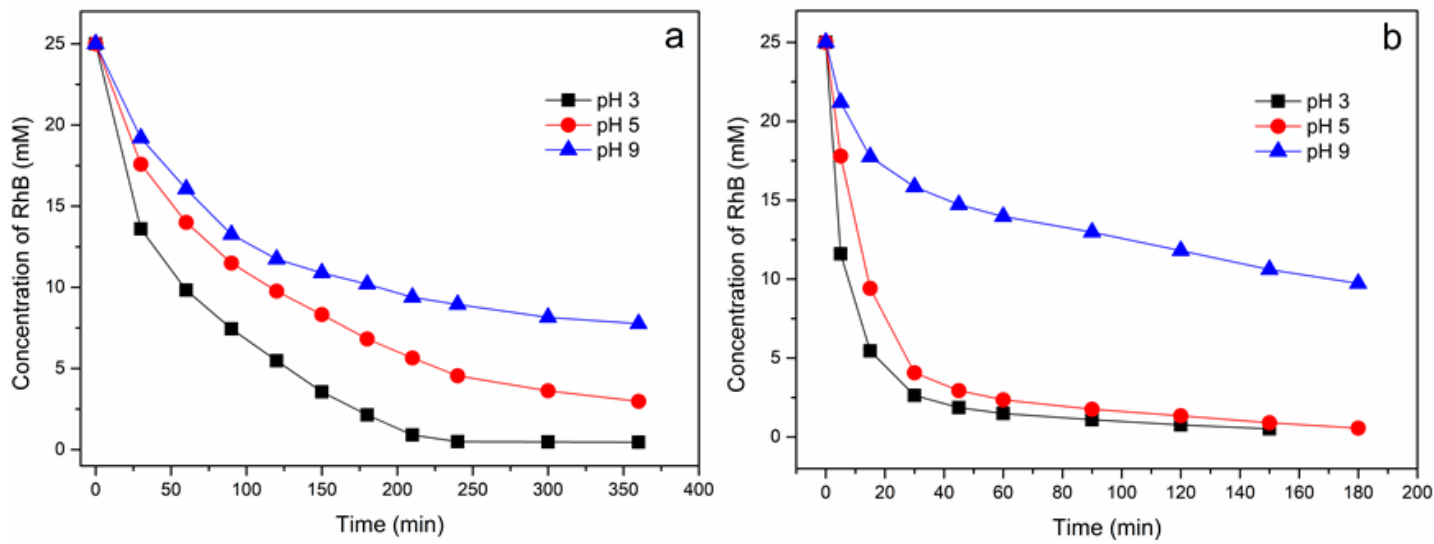

Figure 2. Degradation of RhB in the absence (a) and presence (b) of HA under various $\mathrm{pH}$ conditions. Concentrations: $[$ Schwertmannite $]=0.5 \mathrm{~g} / \mathrm{L},[\mathrm{RhB}]=25 \mathrm{mM},[\mathrm{PS}]=5 \mathrm{mM}$, and $[\mathrm{HA}]=0.5 \mathrm{mM}$.

Although HA can accelerate the transformation from $\mathrm{Fe}(\mathrm{III})$ to $\mathrm{Fe}(\mathrm{II})$ and contribute to the increasing degradation rate of $\mathrm{RhB}$ under acid conditions, high concentration of HA will be counterproductive [15]. It was found that the degradation rate of $\mathrm{RhB}$ increased rapidly with the increasing concentrations of $\mathrm{HA}$ from 0 to $0.5 \mathrm{mM}$ at pH 5, and the concentrations of RhB decreased from $25 \mathrm{mM}$ to $11.5,7.0$ and $1.8 \mathrm{mM}$ in $90 \mathrm{~min}$, respectively (Figure 3). However, the degradation rate of $\mathrm{RhB}$ increased slightly when the concentration of $\mathrm{HA}$ increased from 0.5 to $1.0 \mathrm{mM}$ (Figure 3). The slightly increased degradation rate of $\mathrm{RhB}$ under high $\mathrm{HA}$ concentration might be caused by the removal of radicals by excess $\mathrm{NH}_{3} \mathrm{OH}^{+}[2,3,15]$, which is the main form of $\mathrm{HA}$ (pKa 5.96 at $25^{\circ} \mathrm{C}$ ) at $\mathrm{pH} 3$ and 5 in aqueous solutions [31]. Considering the rate constant of $5.0 \times 10^{8} \mathrm{M}^{-1} \cdot \mathrm{s}^{-1}$ for $\bullet \mathrm{OH}$ and $1.5 \times 10^{7} \mathrm{M}^{-1} \cdot \mathrm{s}^{-1}$ for $\mathrm{SO}_{4}^{\bullet-}, \mathrm{NH}_{3} \mathrm{OH}^{+}$would be the scavenger for $\bullet \mathrm{OH}$ and $\mathrm{SO}$ radicals, as shown in Equations (1) and (2), when the concentration of $\mathrm{NH}_{3} \mathrm{OH}^{+}$is high enough [2,3].

$$
\begin{aligned}
& \mathrm{NH}_{3} \mathrm{OH}^{+}+\bullet \mathrm{OH} \rightarrow \mathrm{OH}^{-}+\text {nitro }- \text { products } \\
& \mathrm{NH}_{3} \mathrm{OH}^{+}+\mathrm{SO}_{4}^{\bullet-} \rightarrow \mathrm{SO}_{4}^{2-}+\text { nitro }- \text { products }
\end{aligned}
$$




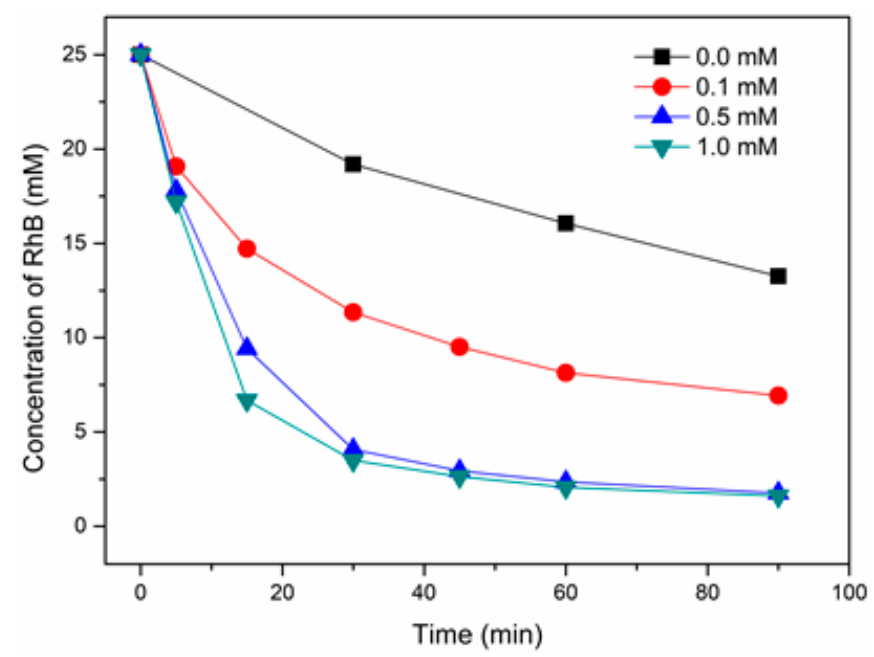

Figure 3. Effect of $\mathrm{HA}$ concentration on $\mathrm{RhB}$ degradation at $\mathrm{pH}$. Concentrations: [Sch] $=0.5 \mathrm{~g} / \mathrm{L}$, $[\mathrm{RhB}]=25 \mathrm{mM},[\mathrm{PS}]=5 \mathrm{mM}$, and $[\mathrm{HA}]=0-1 \mathrm{mM}$.

\subsection{Release Files of Dissolved Iron from Schwertmannite}

Figure 4 shows the release of dissolved iron from schwertmannite during the degradation of $\mathrm{RhB}$ at $\mathrm{pH} 3$ and 5. The dissolved iron was released slowly from schwertmannite without the addition of HA due to the low efficiency of PS activation, and 1.6 and $0.7 \mu \mathrm{M}$ iron released in $120 \mathrm{~min}$ at $\mathrm{pH} 3$ and 5, respectively. However, more $\mathrm{Fe}(\mathrm{III})$ was dissolved and released from schwertmannite in the presence of HA during the degradation of RhB. After the addition of HA, 26.7 and $20.0 \mu \mathrm{M}$ iron was released in $120 \mathrm{~min}$ at $\mathrm{pH} 3$ and 5, respectively. Considering the higher degradation rate of RhB in the presence of HA (Figure $2 b$ ), the increasing release of dissolved iron indicates the acceleration of transformation from Fe(III) to Fe(II) and the improvement of PS activation on schwertmannite.

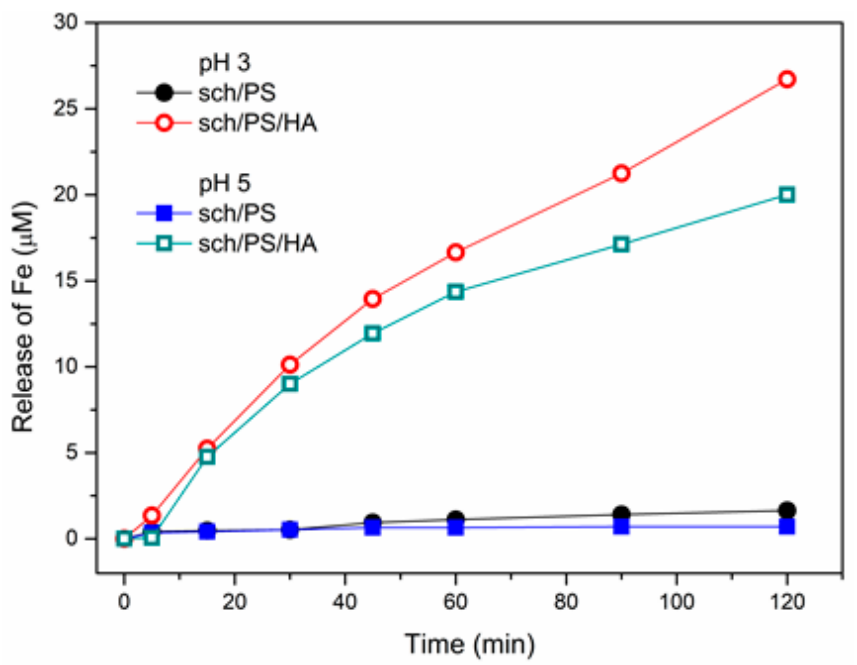

Figure 4. Release files of dissolved iron from schwertmannite during the degradation of RhB under various $\mathrm{pH}$ conditions. Concentrations: $[\mathrm{Sch}]=0.5 \mathrm{~g} / \mathrm{L},[\mathrm{RhB}]=25 \mathrm{mM},[\mathrm{PS}]=5 \mathrm{mM}$, and $[\mathrm{HA}]=0.5 \mathrm{mM}$.

\subsection{Effect of $F e(I I I)$ on the Degradation of RhB}

To investigate the effect of $\mathrm{Fe}(\mathrm{III})$ on the degradation of $\mathrm{RhB}$, ferric chloride $\left(\mathrm{FeCl}_{3} \cdot 6 \mathrm{H}_{2} \mathrm{O}\right)$ was employed and substituted for schwertmannite during the catalytic process. As shown in Figure 5, under the restriction of PS activation, concentrations of $\mathrm{RhB}$ decreased slowly from $25 \mathrm{mM}$ to 8.6 and $12.8 \mathrm{mM}$ in $90 \mathrm{~min}$ at $\mathrm{pH} 3$ and 5, respectively (Figure 5). However, it showed higher degradation 
rate of RhB after the addition of HA: only 1.7 and $3.0 \mathrm{mM} \mathrm{RhB}$ remained at $90 \mathrm{~min}$ at $\mathrm{pH} 3$ and 5, respectively. The addition of HA contributed to the acceleration of transformation from Fe(III) to $\mathrm{Fe}(\mathrm{II})$ due to the reducing capacity, which further improved the generation of radicals from PS activation for the degradation process [15].

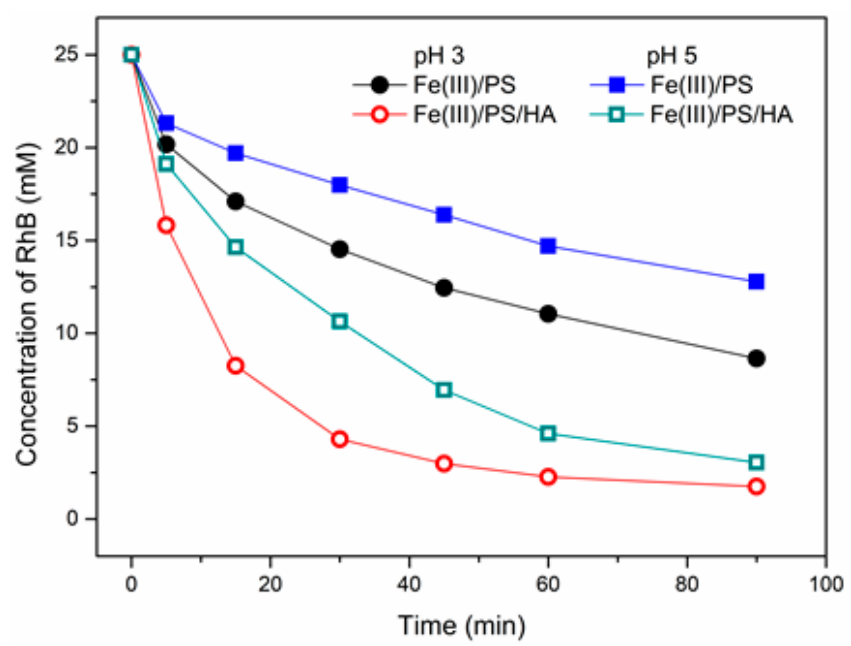

Figure 5. Effect of $\mathrm{Fe}(\mathrm{III})$ on $\mathrm{RhB}$ degradation under various $\mathrm{pH}$ conditions. Homogeneous catalytic degradation of RhB at initial $\mathrm{pH} 3$ and 5. Concentrations: $[\mathrm{Fe}(\mathrm{III})]=25 \mu \mathrm{M},[\mathrm{RhB}]=25 \mathrm{mM},[\mathrm{PS}]=5 \mathrm{mM}$, and $[\mathrm{HA}]=0.5 \mathrm{mM}$.

\subsection{Determination of Kinetic Parameters}

The initial kinetic constants of $\mathrm{RhB}$ degradation were quite different in homogeneous and heterogeneous processed (Figure 6). The initial kinetic constants were obtained by first-order kinetic equation (Equation (3)), which can also be expressed as Equation (4):

$$
\begin{gathered}
d C / d t=-k_{1} C \\
\ln \left(C / C_{0}\right)=-k t
\end{gathered}
$$

where $C$ is the concentration of $\mathrm{RhB}(\mathrm{mM}) ; C_{0}$ is the initial concentration of $\mathrm{RhB}(\mathrm{mM}) ; t$ is time (min); and $k$ is the initial kinetic constant of $\mathrm{RhB}$ degradation $\left(\mathrm{min}^{-1}\right)$. The linear relationship between $\ln \left(C / C_{0}\right)$ and $t$ in heterogeneous and homogeneous process are shown in Figure $6 \mathrm{a}, \mathrm{b}$, and the absolute value of linear slope represents the initial kinetic constant $k$. As shown in Figure 6c, the initial kinetic constants are $1.3 \times 10^{-2}$ and $7.8 \times 10^{-3} \mathrm{~min}^{-1}$ for heterogeneous process and $1.3 \times 10^{-2}$ and $6.9 \times 10^{-3} \mathrm{~min}^{-1}$ for homogeneous process without the addition of $\mathrm{HA}$ at $\mathrm{pH} 3$ and 5, respectively. However, they are $9.8 \times 10^{-2}$ and $6.0 \times 10^{-2} \mathrm{~min}^{-1}$ for heterogeneous process and $5.7 \times 10^{-2}$ and $2.7 \times 10^{-2} \mathrm{~min}^{-1}$ for homogeneous process in the presence of $\mathrm{HA}$ at $\mathrm{pH} 3$ and 5, respectively. Compared with the homogeneous process, more significant improvement of the initial kinetic constant at $\mathrm{pH} 3$ and 5 in heterogeneous process suggests that the activation of PS enhanced by HA is mainly achieved through heterogeneous catalysis at acid conditions despite the existence of homogeneous process. The homogeneous kinetics and iron releasing kinetics can be described as Equations (5) and (6):

$$
\begin{gathered}
d C / d t=-k_{1} C \cdot m \\
d m / d t=-k_{2}\left(m^{*}-m\right)^{r}
\end{gathered}
$$

where $m$ is the concentration of released iron $(\mu \mathrm{M}) ; m^{*}$ is the maximum of released iron concentrations $(\mu \mathrm{M}) ; k_{1}$ and $k_{2}$ are kinetic constants $\left(\mathrm{min}^{-1}\right)$; and $r$ is the activity of iron oxides in the reductive dissolution process. As shown in Figure $6 \mathrm{~d}$, degradations were $16.1 \%$ and $5.8 \%$ at $30 \mathrm{~min}$ by the released 
iron at $\mathrm{pH} 3$ and 5, respectively. Removal of $\mathrm{RhB}$ increased with the increasing concentration of released iron based on time. However, degradations were $89.5 \%$ and $83.7 \%$ at $30 \mathrm{~min}$ by schwertmannite at $\mathrm{pH} 3$ and 5, respectively. This significant difference indicates the dominating degradation on the surface of heterogeneous schwertmannite.
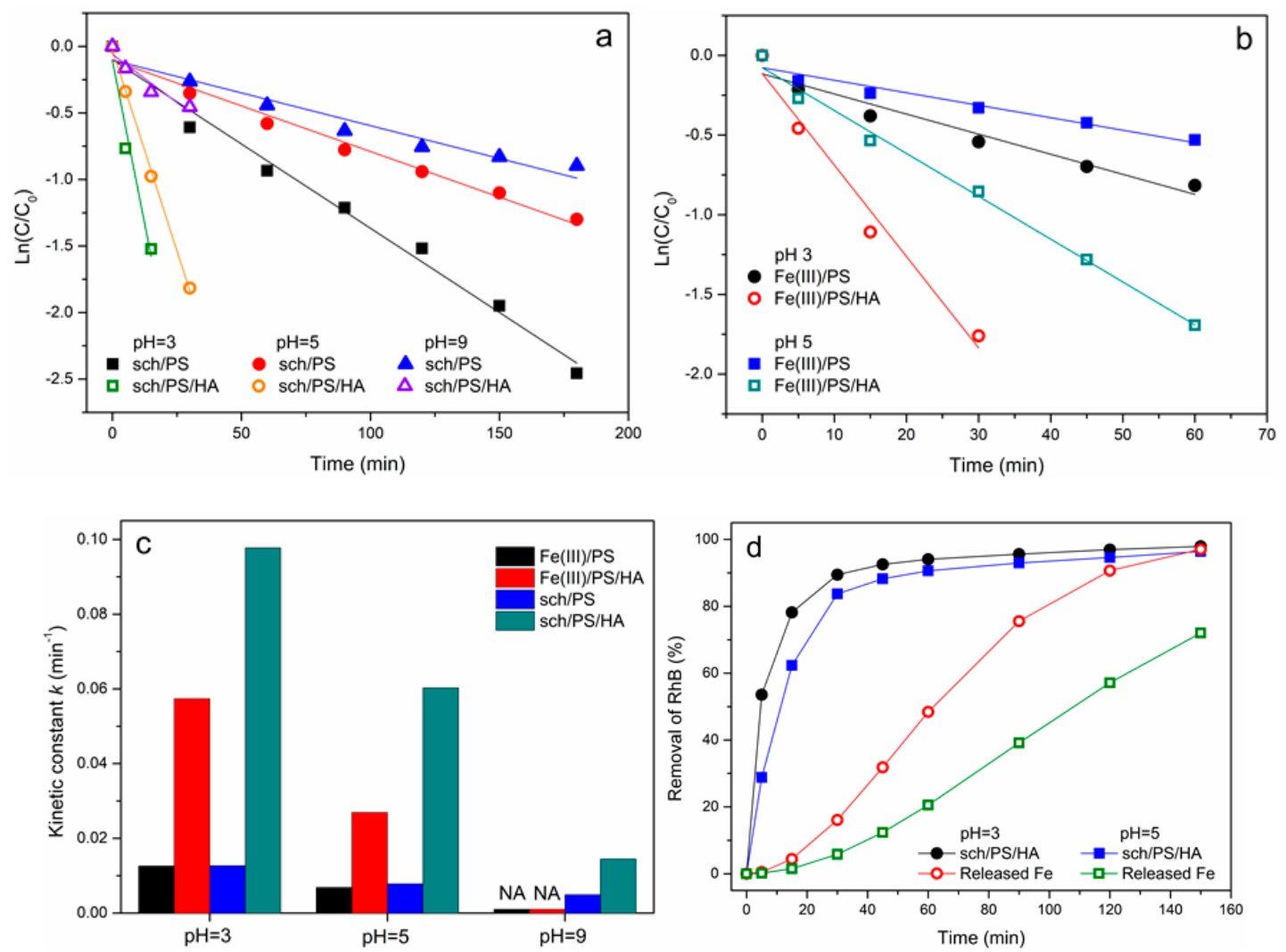

Figure 6. First-order kinetics of RhB degradation in homogeneous and heterogeneous oxidation processes under various $\mathrm{pH}$ conditions. Initial $\mathrm{RhB}$ degradation rates in: (a) Sch/PS and Sch/PS/HA; and (b) Fe(III)/PS and Fe(III)/PS/HA. (c) Effect of HA on initial RhB degradation rates. (d) Effect of released iron by the reductive dissolution during the heterogeneous oxidation process.

\subsection{Comparison of Heterogeneous Process and Homogeneous Process}

To further investigate advantages of heterogeneous process compared with homogeneous process, possible homogeneous and heterogeneous intermediates were provided, as shown in Figure 7, where $\mathrm{Fe}(\mathrm{II})-\mathrm{S}_{2} \mathrm{O}_{8}$ and $\mathrm{FeO}_{4}-\mathrm{S}_{2} \mathrm{O}_{8}$ represent homogeneous and heterogeneous intermediates, respectively. The activation of persulfate would then be considered as the transition of electron from HOMO (Highest Occupied Molecular Orbital) to LUMO (Lowest Unoccupied Molecular Orbital) inside intermediates. Orbital energy analysis of intermediates is listed in Table 1 . The energy difference between HOMO and LUMO indicates the reactivity of intermediates, and they are 4.361, 2.678 and $0.404 \mathrm{eV}$ for $\mathrm{H}_{2} \mathrm{~S}_{2} \mathrm{O}_{8}, \mathrm{Fe}(\mathrm{II})-\mathrm{S}_{2} \mathrm{O}_{8}$ and $\mathrm{FeO}_{4}-\mathrm{S}_{2} \mathrm{O}_{8}$, respectively. It suggests that the heterogeneous intermediate shows the lowest orbital energy for the electron transition, which means higher reactivity than that of homogeneous intermediate. Therefore, the enhanced activation of persulfate is dominated by heterogeneous process. 


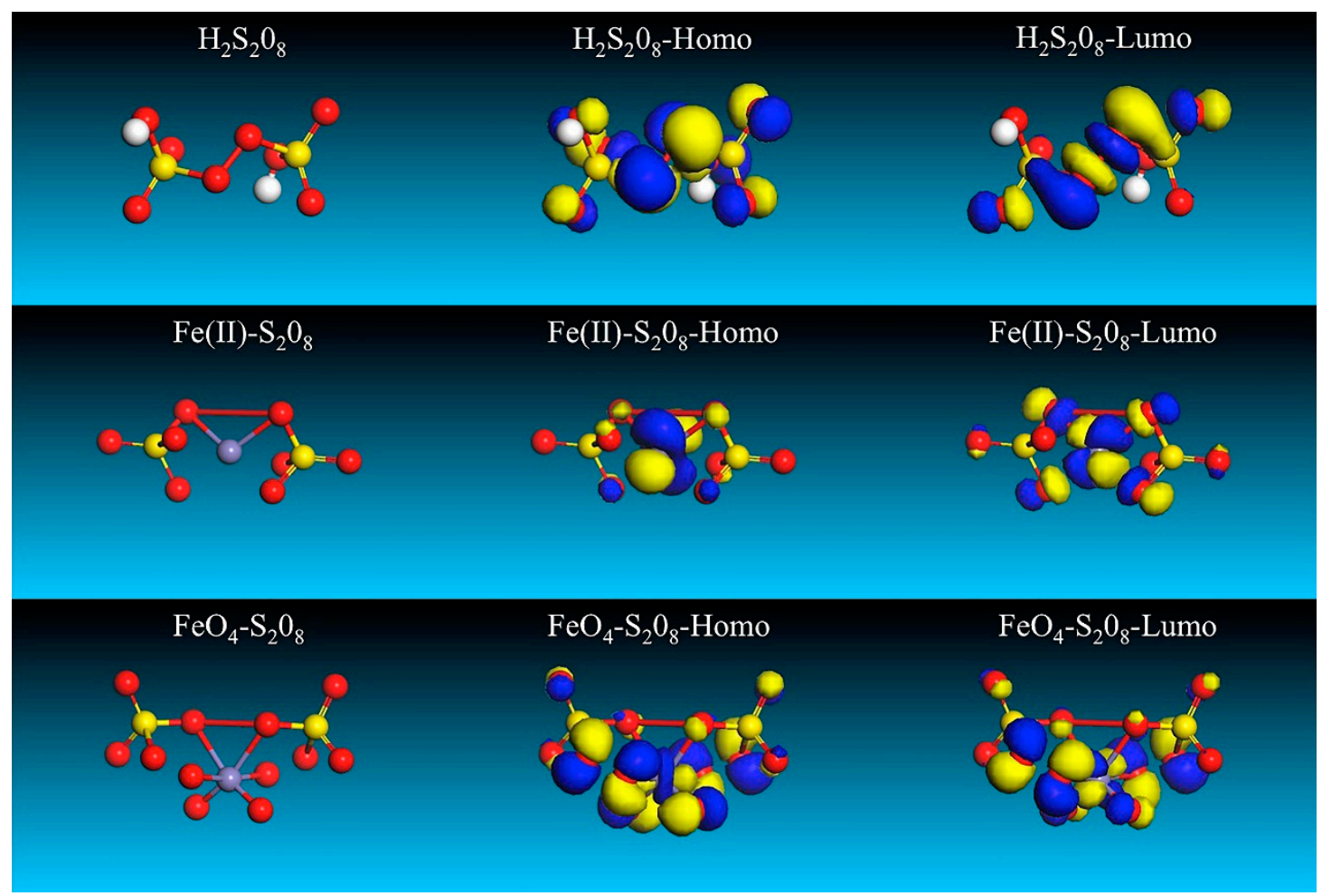

Figure 7. HOMO and LUMO orbital analysis of possible intermediates in homogeneous and heterogeneous process.

Table 1. Orbital energy analysis of homogeneous and heterogeneous intermediates.

\begin{tabular}{cccc}
\hline Species & $\boldsymbol{E}_{\text {HOMO }} / \mathbf{e V}$ & $E_{\text {LUMO }} / \mathbf{e V}$ & $\Delta E / \mathbf{e V}$ \\
\hline $\mathrm{H}_{2} \mathrm{~S}_{2} \mathrm{O}_{8}$ & -11.417 & -2.084 & 9.333 \\
$\mathrm{Fe}(\mathrm{II})-\mathrm{S}_{2} \mathrm{O}_{8}$ & -11.745 & -2.543 & 9.202 \\
$\mathrm{FeO}_{4}-\mathrm{S}_{2} \mathrm{O}_{8}$ & -9.611 & -1.372 & 8.239 \\
\hline
\end{tabular}

\subsection{Effect of $\mathrm{pH}_{\mathrm{pzc}}$ on the Heterogeneous Process}

The $\mathrm{pH}$ point of zero charge $\left(\mathrm{pH}_{\mathrm{pzc}}\right)$ of iron oxides catalysts always plays an important role to change the $\mathrm{pH}$ in system and provide acidic microenvironment in the heterogeneous AOPs [23,32]. As shown in Figure 8a, the $\mathrm{pH}$ decreases from the initial 3, 5 and 9 to the final 2.6, 3.3 and 6.2 in 360 min during the degradation, respectively. Due to the low $\mathrm{pH}_{\mathrm{pzc}}$ of schwertmannite (3.05) [23], schwertmannite could show the potential to release proton into the environment, where the $\mathrm{pH}$ is higher than the $\mathrm{pH}_{\mathrm{pzc}}$ of iron oxides. The $\mathrm{pH}$ of the system would therefore decrease due to the released proton and intermediates formed during the degradation of $\operatorname{RhB}[23,33,34]$.

As shown in Figure $8 b$, the increasing addition of HA finally caused the significant decrease of $\mathrm{pH}$ from the initial 5 to the final 3.4, 2.8 and 2.6 with the increasing HA addition of $0.1,0.5$ and $1.0 \mathrm{mM}$, respectively. Although increasing addition of HA accelerated the transformation from Fe(III) to $\mathrm{Fe}$ (II) for the PS activation, it also resulted in the reductive dissolution of schwertmannite during the degradation process. Therefore, the significant decrease of $\mathrm{pH}$ is achieved by the release of proton from schwertmannite during the dissolution, and the new-formed acid microenvironment exposed by the dissolution process resulted in the higher degradation rate of RhB. 

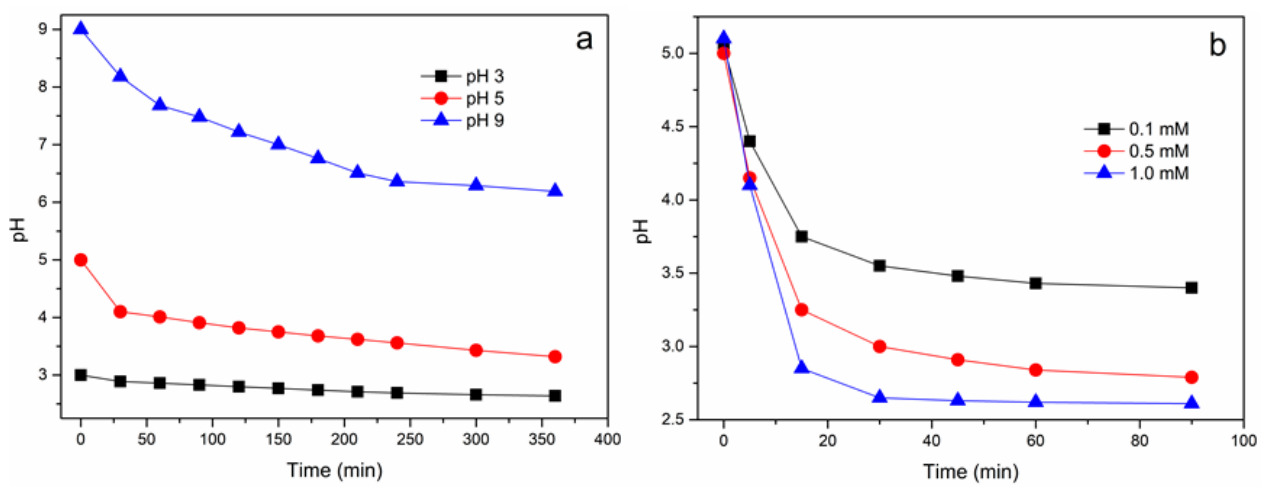

Figure 8. Changes of $\mathrm{pH}$ during the RhB degradation in the absence (a) and presence (b) of HA under various $\mathrm{pH}$ conditions. Concentrations: $[\mathrm{Sch}]=0.5 \mathrm{~g} / \mathrm{L},[\mathrm{RhB}]=25 \mathrm{mM},[\mathrm{PS}]=5 \mathrm{mM}$, and $[\mathrm{HA}]=0-1 \mathrm{mM}$.

\subsection{Activation Mechanism of PS on Schwertmannite in the Presence of HA}

To understand the activation mechanism of PS on schwertmannite, methanol and TBA were employed as scavengers for radicals formed by the PS activation. Figure 9 shows the inhibitory effect of methanol and TBA on the degradation of RhB by PS on schwertmannite in the presence of HA. Concentrations of RhB decreased from $25 \mathrm{mM}$ to 8.0 and $13.8 \mathrm{mM}$ with the increasing addition of 0.1 and $1.0 \mathrm{M}$ methanol, respectively. However, the concentrations of RhB decreased to 4.5 and $11.9 \mathrm{mM}$ in the presence of 0.1 and 1.0 M TBA, respectively. Considering the high rate constants for $\bullet \mathrm{OH}\left(9.7 \times 10^{8} \mathrm{M}^{-1} \cdot \mathrm{s}^{-1}\right)$ [3] and $\mathrm{SO}_{4}^{\bullet-}\left(2.5 \times 10^{7} \mathrm{M}^{-1} \cdot \mathrm{s}^{-1}\right)$ [2], methanol is considered as an effective scavenger for both $\bullet \mathrm{OH}$ and $\mathrm{SO}_{4}^{--}$, while TBA is only an effective scavenger for $\bullet \mathrm{OH}$ $\left(6.0 \times 10^{8} \mathrm{M}^{-1} \cdot \mathrm{s}^{-1}\right)$ [3] but not for $\mathrm{SO}_{4}^{\bullet-}\left(8.0 \times 10^{5} \mathrm{M}^{-1} \cdot \mathrm{s}^{-1}\right)$ [2] due to its much slower rate constant for $\mathrm{SO}_{4}^{\bullet-}$. According to the investigation by Zou et al. [15], contribution of $\mathrm{SO}_{5}^{\bullet-}$ on the degradation of RhB was excluded. Therefore, the lower efficiency of TBA than methanol for the inhibition of RhB degradation indicates that both $\bullet \mathrm{OH}$ and $\mathrm{SO}_{4}^{\bullet-}$ are the reactive oxidants that formed by the activation of PS on schwertmannite described as Equations (7)-(12). The possible activation mechanism of PS on schwertmannite in the presence of HA is proposed in Scheme 1.

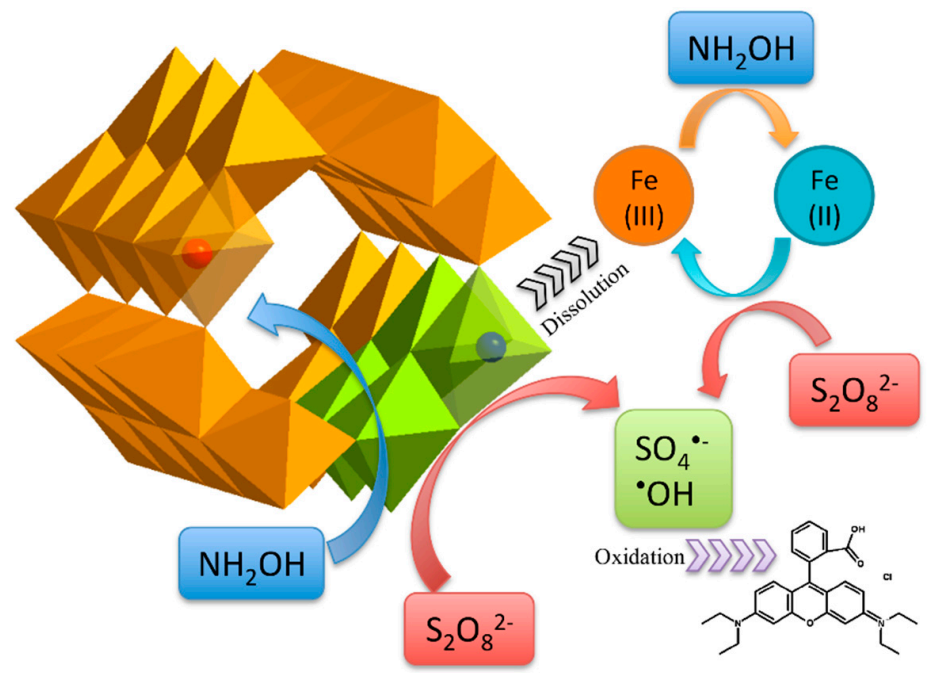

Scheme 1. Activation of mechanism of PS on schwertmannite in the presence of HA.

In strongly acid solutions, persulfate decomposes according to Equations (7) and (8), while, in alkaline, neutral and dilute acid solutions, the decomposition follows Equation (9) [35]. Previous studies 
suggested that persulfate decomposition in aqueous solutions is first order and that the reaction is catalyzed by hydrogen ion $[35,36]$. Meanwhile, there are many hydrogen ions on the surface of schwertmannite due to low $\mathrm{pH}_{\mathrm{pzc}}$ (3.05) [23], which results in the surface of iron oxides existing as the form of $\mathrm{Fe}-\mathrm{OH}_{2}{ }^{+}$[37]. This contributes to the decomposition of persulfate according to Equations (7) and (8), and then the forming of the $\mathrm{Fe}-\mathrm{OOSO}_{3}$ peroxo metal complex according to Equations (11) and (12).

$$
\begin{gathered}
\mathrm{S}_{2} \mathrm{O}_{8}^{2-}+\mathrm{H}_{2} \mathrm{O} \rightarrow \mathrm{SO}_{5}^{2-}+\mathrm{SO}_{4}^{2-}+2 \mathrm{H}^{+} \\
\mathrm{SO}_{5}^{2-}+\mathrm{H}_{2} \mathrm{O} \rightarrow \mathrm{SO}_{4}^{2-}+\mathrm{H}_{2} \mathrm{O}_{2} \\
\mathrm{~S}_{2} \mathrm{O}_{8}^{2-}+\mathrm{H}_{2} \mathrm{O} \rightarrow 2 \mathrm{HSO}_{4}^{-}+1 / 2 \mathrm{O}_{2} \\
\equiv \mathrm{Fe}(\mathrm{III})+\mathrm{NH}_{3} \mathrm{OH}^{+} \rightarrow \equiv \mathrm{Fe}(\mathrm{II})+\text { nitro }- \text { products } \\
\equiv \mathrm{Fe}(\mathrm{II})-\mathrm{OH}_{2}^{+}+\mathrm{S}_{2} \mathrm{O}_{8}^{2-} \rightarrow \equiv \mathrm{Fe}(\mathrm{II})-\mathrm{OOSO}_{3}^{-}+\mathrm{SO}_{4}^{2-}+2 \mathrm{H}^{+} \\
\equiv \mathrm{Fe}(\mathrm{III})-\mathrm{OH}_{2}^{+}+\mathrm{S}_{2} \mathrm{O}_{8}^{2-} \rightarrow \equiv \mathrm{Fe}(\mathrm{III})-\mathrm{OOSO}_{3}^{-}+\mathrm{SO}_{4}^{2-}+2 \mathrm{H}^{+} \\
\equiv \mathrm{Fe}(\mathrm{II})-\mathrm{OOSO}_{3}^{-}+\mathrm{H}_{2} \mathrm{O} \rightarrow \equiv \mathrm{Fe}(\mathrm{II})-\mathrm{OH}+\mathrm{SO}_{4}^{--}+\mathrm{OH}^{-} \\
\equiv \mathrm{Fe}(\mathrm{II})-\mathrm{OOSO}_{3}^{-}+\mathrm{H}_{2} \mathrm{O} \rightarrow \equiv \mathrm{Fe}(\mathrm{II})-\mathrm{OH}+\bullet \mathrm{OH}^{-} \mathrm{SO}_{4}^{2-} \\
\equiv \mathrm{Fe}(\mathrm{III})-\mathrm{OOSO}_{3}^{-}+\mathrm{H}_{2} \mathrm{O} \rightarrow \equiv \mathrm{Fe}(\mathrm{II})+\mathrm{O}_{2}+\mathrm{SO}_{4}^{2-}+2 \mathrm{H}^{+}
\end{gathered}
$$

Previous studies suggested that decomposition of $\mathrm{H}_{2} \mathrm{O}_{2}$ on transition metal oxide surface was always achieved by the formation of the peroxo metal complex [23,38-41]. Similar to the decomposition mechanism of $\mathrm{H}_{2} \mathrm{O}_{2}$ on transition metal oxide surface, the surface hydroxyl group (Fe(III)-OH) on schwertmannite can be substituted by peroxo group $\left(\mathrm{O}_{3} \mathrm{~S}-\mathrm{OO}-\mathrm{SO}_{3}\right)$ of $\mathrm{PS}$ to form $\mathrm{Fe}(\mathrm{II})-\mathrm{OOSO}_{3}$ or $\mathrm{Fe}(\mathrm{III})-\mathrm{OOSO}_{3}$ peroxo metal complex (Equations (11) and (12)). After that, the complex decomposes to form radicals (Equations (13)-(15)), and the Fe(II)-OH formed by Equation (10) will transfer to $\mathrm{Fe}(\mathrm{III})-\mathrm{OH}$ again on the surface for heterogeneous process or aqueous $\mathrm{Fe}(\mathrm{III})$ released into solutions for the homogeneous process.

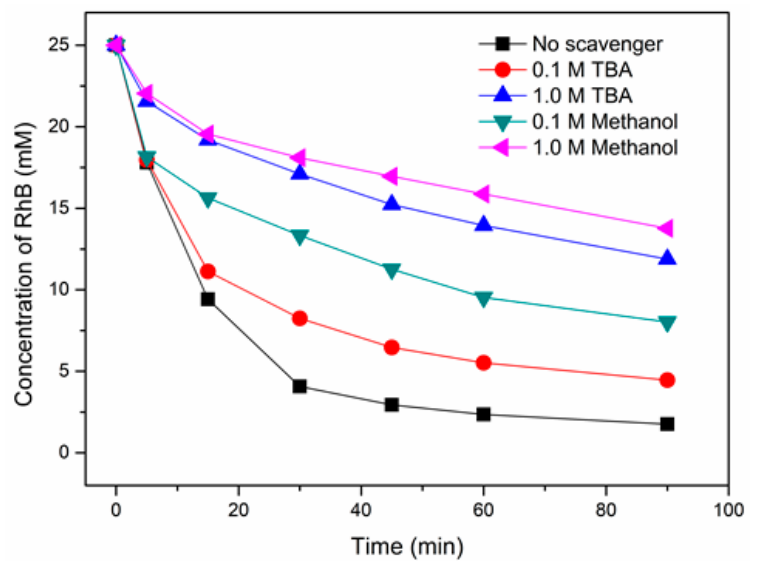

Figure 9. Inhibition effect of radical scavengers on $\mathrm{RhB}$ degradation in the presence of $\mathrm{HA}$ at $\mathrm{pH} 5$. Concentrations: $[\mathrm{Sch}]=0.5 \mathrm{~g} / \mathrm{L},[\mathrm{RhB}]=25 \mathrm{mM},[\mathrm{PS}]=5 \mathrm{mM},[\mathrm{HA}]=0.5 \mathrm{mM},[\mathrm{TBA}]=0-1 \mathrm{mM}$, and $[$ Methanol $]=0-1 \mathrm{mM}$.

\section{Conclusions}

It was found that the addition of HA was more for the degradation of $\mathrm{RhB}$ under acid conditions. Significant release of dissolved iron from schwertmannite was obtained due to the reductive dissolution process. Although the aqueous $\mathrm{Fe}(\mathrm{II})$ could be achieved by the involved HA, the transformation from $\mathrm{Fe}(\mathrm{III})$ to $\mathrm{Fe}$ (II) was accelerated through the reduction of $\mathrm{Fe}(\mathrm{III})-\mathrm{OH}$ to $\mathrm{Fe}(\mathrm{II})-\mathrm{OH}$ on the surface of 
schwertmannite. The newly formed $\mathrm{Fe}(\mathrm{II})-\mathrm{OH}_{2}{ }^{+}$contributed to the improvement of PS activation for the generation of $\bullet \mathrm{OH}$ and $\mathrm{SO}_{4}^{\bullet-}$ radicals, which dominated the degradation process.

Author Contributions: Conceptualization, J.R and B.Y.; Methodology, B.Y.; Software, B.Y.; Validation, J.R.; Formal Analysis, J.R. and B.Y.; Investigation, B.Y.; Writing-Original Draft Preparation, B.Y.; Writing-Review \& Editing, J.R.; Visualization, B.Y.; Supervision, J.R.; Project Administration, J.R.; Funding Acquisition, J.R.

Funding: This work was supported by the Guizhou Province Science and Technology Department-Guizhou Institute of Technology Joint Fund (Guizhou Science and Technology Agency LH [2015] 7097).

Acknowledgments: This work was supported by the Guizhou Province Science and Technology Department-Guizhou Institute of Technology Joint Fund (Guizhou Science and Technology Agency LH [2015] 7097).

Conflicts of Interest: The authors declare no conflict of interest.

\section{References}

1. Pereira, M.C.; Oliveira, L.C.A.; Murad, E. Iron oxide catalysts: Fenton and Fenton-like reactions a review. Clay Miner. 2012, 47, 285-302. [CrossRef]

2. Neta, P.; Huie, R.E.; Ross, A.B. Rate constants for reactions of inorganic radicals in aqueous solution. J. Phys. Chem. Ref. Data 1988, 17, 1027-1284. [CrossRef]

3. Buxton, G.V.; Greenstock, C.L.; Helman, W.P.; Ross, A.B. Critical review of rate constants for reactions of hydrated electrons, hydrogen atoms and hydroxyl radicals $\left(\bullet \mathrm{OH} / \bullet \mathrm{O}^{-}\right)$in aqueous solution. J. Phys. Chem. Ref. Data 1988, 17, 513-886. [CrossRef]

4. Anipsitakis, G.P.; Dionysiou, D.D. Degradation of organic contaminants in water with sulfate radicals generated by the conjunction of peroxymonosulfate with cobalt. Environ. Sci. Technol. 2003, 37, 4790-4797. [CrossRef] [PubMed]

5. Anipsitakis, G.P.; Dionysiou, D.D. Radical generation by the interaction of transition metals with common oxidants. Environ. Sci. Technol. 2004, 38, 3705-3712. [CrossRef] [PubMed]

6. Chan, K.; Chu, W. Degradation of atrazine by cobalt-mediated activation of peroxymonosulfate: Different cobalt counteranions in homogenous process and cobalt oxide catalysts in photolytic heterogeneous process. Water Res. 2009, 43, 2513-2521. [CrossRef] [PubMed]

7. Guan, Y.H.; Ma, J.; Li, X.C.; Fang, J.Y.; Chen, L.W. Influence of pH on the formation of sulfate and hydroxyl radicals in the UV/Peroxymonosulfate system. Environ. Sci. Technol. 2011, 45, 9308-9314. [CrossRef] [PubMed]

8. Hori, H.; Nagaoka, Y.; Murayama, M.; Kutsuna, S. Efficient decomposition of perfluorocarboxylic acids and alternative fluorochemical surfactants in hot water. Environ. Sci. Technol. 2008, 42, 7438-7443. [CrossRef] [PubMed]

9. Hori, H.; Yamamoto, A.; Hayakawa, E.; Taniyasu, S.; Yamashita, N.; Kutsuna, S.; Kiatagawa, H.; Arakawa, R. Efficient decomposition of environmentally persistent perfluorocarboxylic acids by use of persulfate as a photochemical oxidant. Environ. Sci. Technol. 2005, 39, 2383-2388. [CrossRef] [PubMed]

10. Lau, T.K.; Chu, W.; Graham, N.J.D. The aqueous degradation of butylated hydroxyanisole by $\mathrm{UV} / \mathrm{S}_{2} \mathrm{O}_{8}{ }^{2-}$ : Study of reaction mechanisms via dimerization and mineralization. Environ. Sci. Technol. 2007, 41, 613-619. [CrossRef] [PubMed]

11. Rastogi, A.; Ai-Abed, S.R.; Dionysiou, D.D. Sulfate radical-based ferrous-peroxymonosulfate oxidative system for PCBs degradation in aqueous and sediment systems. Appl. Catal. B 2009, 85, 171-179. [CrossRef]

12. Waldemer, R.H.; Tratnyek, P.G.; Johnson, R.L.; Nurmi, J.T. Oxidation of chlorinated ethenes by heat-activated persulfate: Kinetics and products. Environ. Sci. Technol. 2007, 41, 1010-1015. [CrossRef] [PubMed]

13. Liang, C.; Huang, C.F.; Chen, Y.J. Potential for activated persulfate degradation of BTEX contamination. Water Res. 2008, 42, 4091-4100. [CrossRef] [PubMed]

14. Oh, S.Y.; Kim, H.W.; Park, J.M.; Park, H.S.; Yoon, C. Oxidation of polyvinyl alcohol by persulfate activated with heat, $\mathrm{Fe}^{2+}$, and zero-valent iron. J. Hazard. Mater. 2009, 168, 346-351. [CrossRef] [PubMed]

15. Zou, J.; Ma, J.; Chen, L.; Li, X.; Guan, Y.; Xie, P.; Pan, C. Rapid acceleration of ferrous iron/peroxymonosulfate oxidation of organic pollutants by promoting Fe(III)/Fe(II) cycle with hydroxylamine. Environ. Sci. Technol. 2013, 47, 11685-11691. [CrossRef] [PubMed] 
16. Anipsitakis, G.P.; Dionysiou, D.D. Transition metal/UV-based advanced oxidation technologies for water decontamination. Appl. Catal. B 2004, 54, 155-163. [CrossRef]

17. Wang, Y.; Chu, W. Degradation of 2,4,5-trichlorophenoxyacetic acid by a novel Electro-Fe(II)/Oxone process using iron sheet as the sacrificial anode. Water Res. 2011, 45, 3883-3889. [CrossRef] [PubMed]

18. Chen, L.W.; Ma, J.; Li, X.C.; Zhang, J.; Fang, J.Y.; Guan, Y.H.; Xie, P.C. Strong enhancement on Fenton oxidation by addition of hydroxylamine to accelerate the ferric and ferrous iron cycles. Environ. Sci. Technol. 2011, 45, 3925-3930. [CrossRef] [PubMed]

19. Rastogi, A.; Al-Abed, S.R.; Dionysiou, D.D. Effect of inorganic, synthetic and naturally occurring chelating agents on Fe(II) mediated advanced oxidation of chlorophenols. Water Res. 2009, 43, 684-694. [CrossRef] [PubMed]

20. Ahmad, M.; Teel, A.L.; Watts, R.J. Persulfate activation by subsurface minerals. J. Contam. Hydrol. 2010, 115, 34-45. [CrossRef] [PubMed]

21. Chou, S.; Huang, C.; Huang, Y.H. Heterogeneous and homogeneous catalytic oxidation by supported $\gamma$-FeOOH in a fluidized-bed reactor: Kinetic approach. Environ. Sci. Technol. 2001, 35, 1247-1251. [CrossRef] [PubMed]

22. Do, S.H.; Kwon, Y.J.; Kong, S.H. Effect of metal oxides on the reactivity of persulfate/Fe(II) in the remediation of diesel-contaminated soil and sand. J. Hazard. Mater. 2010, 182, 933-936. [CrossRef] [PubMed]

23. Wang, W.M.; Jia, S.X. Han Schwertmannite as a new Fenton-like catalyst in the oxidation of phenol by $\mathrm{H}_{2} \mathrm{O}_{2}$. J. Hazard. Mater. 2013, 262, 412-419. [CrossRef] [PubMed]

24. Zhang, T.; Zhu, H.; Croue, J.P. Production of sulfate radical from peroxymonosulfate induced by a magnetically separable $\mathrm{CuFe}_{2} \mathrm{O}_{4}$ spinel in water: Efficiency, stability, and mechanism. Environ. Sci. Technol. 2013, 47, 2784-2791. [CrossRef] [PubMed]

25. Krishna, M.C.; Degraff, W.; Hankovszky, O.H.; Cecília, P.; Kálai, T.; Jeko, J.; Russo, A.; Mitchell, J.B.; Hideg, K. Studies of structure-activity relationship of nitroxide free radicals and their precursors as modifiers against oxidative damage. J. Med. Chem. 1998, 41, 3477-3492. [CrossRef] [PubMed]

26. Bigham, J.M.; Schwertmann, U.; Murad, E.; Carlson, L. A poorly crystallized oxyhydroxysulfate of iron formed by bacterial oxidation of Fe(II) in acid mine waters. Geochim. Cosmochim. Acta 1990, 54, 2743-2758. [CrossRef]

27. Bigham, J.M.; Schwertmann, U.; Traina, S.J.; Winland, R.L.; Wolf, M. Schwertmannite and the chemical modeling of iron in acid sulfate waters. Geochim. Cosmochim. Acta 1996, 60, 2111-2121. [CrossRef]

28. Bulat, F.A.; Chamorro, E.; Fuentealba, P.; Toro-Labbé, A. Condensation of frontier molecular orbital fukui functions. J. Phys. Chem. A 2004, 108, 342-349. [CrossRef]

29. Harvey, A.E., Jr.; Smart, J.A.; Amis, E. Simultaneous spectrophotometric determination of iron(II) and total iron with 1,10-phenanthroline. Anal. Chem. 1955, 27, 26-29. [CrossRef]

30. Herrera, L.; Ruiz, P.; Aguillon, J.C.; Fehrmann, A. A new spectrophotometric method for the determination of ferrous iron in the presence of ferric iron. J. Chem. Technol. Biotechnol. 1989, 44, 171-181. [CrossRef]

31. Robinson, R.; Bower, V. The ionization constant of hydroxylamine. J. Phys. Chem. 1961, 65, 1279-1280. [CrossRef]

32. Huang, C.P.; Huang, Y.H. Comparison of catalytic decomposition of hydrogen peroxide and catalytic degradation of phenol by immobilized iron oxides. Appl. Catal. A 2008, 346, 140-148. [CrossRef]

33. Tian, S.H.; Tu, Y.T.; Chen, D.S.; Chen, X.; Xiong, Y. Degradation of acid orange II at neutral pH using $\mathrm{Fe}_{2}\left(\mathrm{MoO}_{4}\right)_{3}$ as a heterogeneous Fenton-like catalyst. Biochem. Eng. J. 2011, 169, 31-37. [CrossRef]

34. Zazo, J.; Casas, J.; Mohedano, A.; Gilarranz, M.; Rodriguez, J. Chemical pathway and kinetics of phenol oxidation by Fenton's reagent. Environ. Sci. Technol. 2005, 39, 9295-9302. [CrossRef] [PubMed]

35. Kolthoff, I.M.; Miller, I.K. The chemistry of persulfate. I. The kinetics and mechanism of the decomposition of the persulfate ion in aqueous medium. J. Am. Chem. Soc. 1951, 73, 3055-3059. [CrossRef]

36. Green, L.; Masson, O. CCXIX.-The dynamics of the decomposition of persulphuric acid and its salts in aqueous solution. J. Am. Chem. Soc. Trans. 1910, 97, 2083-2099. [CrossRef]

37. Cornell, R.M.; Schwertmann, U. The Iron Oxides: Structure, Properties, Reactions, Occurrences and Uses; Wiley-VCH: Weinheim, Germany, 2003.

38. Bonino, F.; Damin, A.; Ricchiardi, G. Ti-peroxo species in the TS- $1 / \mathrm{H}_{2} \mathrm{O}_{2} / \mathrm{H}_{2} \mathrm{O}$ system. J. Phys. Chem. B 2004, 108, 3573-3583. [CrossRef] 
39. Giamello, E.; Calosso, L.; Fubini, B.; Geobaldo, F. Evidence of stable hydroxyl radicals and other oxygen radical species generated by interaction of hydrogen peroxide with magnesium oxide. J. Phys. Chem. 1993, 97, 5735-5740. [CrossRef]

40. Kim, D.H.; Bokare, A.D.; Koo, M.S.; Choi, W. Heterogeneous catalytic oxidation of As(III) on nonferrous metal oxides in the presence of $\mathrm{H}_{2} \mathrm{O}_{2}$. Environ. Sci. Technol. 2015, 49, 3506-3513. [CrossRef] [PubMed]

41. Lousada, C.M.; Johansson, A.J.; Brinck, T.; Jonsson, M. Mechanism of $\mathrm{H}_{2} \mathrm{O}_{2}$ decomposition on transition metal oxide surfaces. J. Phys. Chem. C 2012, 116, 9533-9543. [CrossRef]

2018 by the authors. Licensee MDPI, Basel, Switzerland. This article is an open access article distributed under the terms and conditions of the Creative Commons Attribution (CC BY) license (http:/ / creativecommons.org/licenses/by/4.0/). 